NBER WORKING PAPER SERIES

\title{
PATENTS, INNOVATION, AND DEVELOPMENT
}

\author{
Bronwyn H. Hall \\ Working Paper 27203 \\ http://www.nber.org/papers/w27203 \\ NATIONAL BUREAU OF ECONOMIC RESEARCH \\ 1050 Massachusetts Avenue \\ Cambridge, MA 02138 \\ May 2020
}

This paper was written for the Inaugural Penrose Lectures at SOAS, London, in March 2018. I am grateful to the organizer, Christine Oughton, for giving me the opportunity to present this work. The views expressed herein are those of the author and do not necessarily reflect the views of the National Bureau of Economic Research.

NBER working papers are circulated for discussion and comment purposes. They have not been peer-reviewed or been subject to the review by the NBER Board of Directors that accompanies official NBER publications.

(C) 2020 by Bronwyn H. Hall. All rights reserved. Short sections of text, not to exceed two paragraphs, may be quoted without explicit permission provided that full credit, including ( $)$ notice, is given to the source. 
Patents, Innovation, and Development

Bronwyn H. Hall

NBER Working Paper No. 27203

May 2020

JEL No. L65,O25,O30,O34

\begin{abstract}
$\underline{\text { ABSTRACT }}$
I survey some recent research on the role of patents in encouraging innovation and growth in developing economies, beginning with a brief history of international patent systems and facts about the current use of patents around the world. I discuss research on the implications of patents for international technology transfer and domestic innovation. This is followed by a review of recent work by myself and co-authors on regional patent systems, the impact of patents on firm performance, and the impact on pharmaceutical patenting and domestic innovation. The conclusion suggests that patents may be relatively unimportant in development, even for middle income countries.
\end{abstract}

Bronwyn H. Hall

University of California, Berkeley

Economics Department

123 Tamalpais Road

Berkeley, CA 94708

and NBER

bhhall@nber.org 


\section{Introduction}

In her 1951 thesis on the international patent system, Edith Penrose concluded the following statement:

"Up to the present, the regime for the international protection of patent rights has been developed primarily in the interest of patentees. The gains to be derived from an extension of the patent system have been stressed, but the concomitant increase in social costs has been seriously neglected. So far as it goes, the International Convention has not been to any important extent incompatible with the best interests of the world economy. Nonetheless, the Convention in no way helps to alleviate the restrictions on trade and industrial activity which unregulated international patenting permits. A reconsideration of its provisions from this point of view is in order."

(Penrose, 1951, p. 233.) ${ }^{2}$

Since the time she wrote this passage, there has been an enormous growth of patenting around the world, some of it clearly coincidental with the development process, especially in East Asian countries. However at the present time, if we replace the words "International Convention" with "TRIPS (The Agreement on Trade-Related Aspects of Intellectual Property Rights)", the uneven benefits and costs suggested by this paragraph may be as true as ever. In her 1973 Economic Journal article Penrose highlighted the disadvantages of a one-sizefits-all patent system for developing countries and many of her concerns may remain valid today.

As a consequence of reservations similar to those expressed by Penrose, a large amount of research on the relationship between patents, innovation, and development has been produced over the past few decades, much of it empirical in nature. The conclusions from the theoretical literature on the choice of IP system are fairly clear: in the absence of any kind of coordinated action, more developed countries will have stronger IP protection than less developed (Grossman and Lai 2004; Angeles 2005). In addition, harmonization generally leads to levels of IP protection that are higher than the social optimum, at least in the less developed countries (Scotchmer (2004). As these models predict, the tendency is for IP protection strength to harmonize upward rather than downward. However, the theory is less clear about the consequences of different levels of IP protection for development. As Fink and Maskus stress in the introduction to their edited volume on the topic, "...many effects of stronger IPR standards are theoretically ambiguous and thus need to be subjected to empirical analysis." (Fink and Maskus 2005: 2)

\footnotetext{
2 "International Convention" here refers to the Paris Convention of 1883, which specified national treatment for inventors from all signatory countries (42 countries at the time she wrote) and a period of priority after filing in one of the countries during which filings may be submitted to other countries, along with a number of other provisions. At the present time the number of contracting parties to the Paris Convention is 177. See http://www.wipo.int/treaties/en/ip/paris/
} 
Two additional edited books on the topic have recently been published: Ahn et al. 2014 and Cimoli et al. 2014. It is worth noting that although the titles of these books contain the phrase "intellectual property," the majority of the papers they contain concern patents rather than other forms of intellectual property. This reflects both data availability and the relative importance of patents in the thinking of many policymakers and firms. The present paper is no exception to this rule, although later on it will become obvious that the use of trademarks by domestic entities may be a more important form of IP in the course of development.

Given the ample coverage of this broad topic in the volumes cited above, the present article offers a only a brief and selective review of what economists have learned about the relationship between the international patent systems and the development of economies during the decades since Penrose's work. The review is coupled with a more detailed look at the research output of three new empirical investigations by the author and her co-authors into the role of patents in middle income economies: 1) What happens to patenting and innovation when middle income countries join a regional patent system? (Hall and Helmers 2019); 2) Are patents and other IP related to firm performance in rapidly developing economy? (Fink, Hall, and Helmers 2018); and 3) Do pharmaceutical patents in a middle income country play a positive role in pharmaceutical innovation in that country? (AbudSittler, Hall, and Helmers 2015).

\section{A brief patent primer ${ }^{3}$}

Patents have a long history, although some of the earliest patents are simply the grant of a legal monopoly in a particular good rather than protection of an invention from imitation. Early examples of technology-related patents are Brunelleschi's patent on a boat designed to carry marble up the Arno River, issued by the Florentine government in 1421 (Prager 1946), the Venetian patent law of 1474 , and various patent monopolies granted by the English crown between the 15 th and 17 th centuries. The modern patent, which requires a working model or written description of an invention, dates from the 18th century, first in Britain (1718) and then in the United States (1790), followed closely by France (in both the latter two cases one of the consequences of a revolution). ${ }^{4}$ Many other Continental European countries introduced patents during the 19th century, as did Japan (JPO, 2006) and India (James, 2007). During the 20th century, the use of patent systems became almost universal and the signing of the TRIPS agreement has ensured that all countries who are members of the World Trade Organization will have at least a minimal level of patent protection.

In 1883 the Paris Convention for the Protection of Industrial Property guaranteed national treatment of patent applicants from any country that was a party to it. Its most important provision gave applicants who were nationals or residents of one member state the right to

3 This section of the paper is a revised and updated section from Hall and Harhoff (2012).

${ }^{4}$ Ladas and Parry (2003). See also the EPO and USPTO websites (EPO, 2007a and USPTO, 2007). 
file an application in their own country and then, as long as an application was filed in another country that was a member of the treaty within a specified time (now 12 months) to have the date of filing in the home country count as the effective filing date in that other country (the 'priority date'). This is an important feature of the patent system, as it enables worldwide priority to be obtained for an invention originating in any one country, in addition to ensuring that in principle all inventors are treated equally by the system, regardless of the country from which they come. ${ }^{5}$

Although the process for granting a patent varies slightly according to the jurisdiction for which protection is desired, the adoption of the TRIPS agreement in 1995 ensures that it is approximately the same everywhere in the world. This agreement requires its member countries to make patent protection available for any product or process invention in any field of technology with only a few specified exceptions. It also requires them to make the term of protection available for not less than a period of 20 years from the date of filing the patent application. As of February 2020, 164 countries are signatories to this agreement and 28 countries are designated as "observers."

The World Intellectual Property Organization (WIPO) has almost 200 member states and lists an equivalent number of national patent offices and industrial property offices on its website. In general, the patent right extends only within the border of the jurisdiction that has granted it (usually but not always a country). An important exception to this rule is the European system, where it is possible to file a patent application at the European Patent Office (EPO) that will become a set of national patent rights in several European countries at the time of issue (EPO, 2006). A similar situation exists with respect to the African Regional Intellectual Property Organization (ARIPO, with 19 African member states), the Organisation Africaine de la Propriété Intellectuelle (OAPI, with 17 Francophone African member states) and EAPO (Eurasian Patent Organization, with 9 member states from the former USSR). ${ }^{6}$

The Patent Cooperation Treaty (PCT) came into existence in 1978, and now has 153 countries as contracting signatories. Any resident or national of a contracting state of the PCT may file an international application under the PCT that specifies the office which should conduct the search. The PCT application serves as an application filed in each designated contracting state. However, in order to obtain patent protection in a particular state, a patent needs to be granted by that state to the claimed invention contained in the international application. The advantage of a PCT application is that fewer searches need to be conducted and the process is therefore less expensive. Thus, although application and search are to some extent standardized across offices, grants are not. In fact, 94 per cent of the PCT applications go to one of five patent offices for search: those in Europe (35\%), Japan

\footnotetext{
${ }^{5}$ For a number of reasons (linguistic, variations in the legal system, policies targeted to domestic inventors, etc.), this principle is not always completely achieved (de Rassenfosse et al., 2019).

${ }^{6}$ There is also the GCC (Patent Office of the Cooperation Council for the Arab States of the Gulf), but this organization is not a signatory of the Paris Convention nor a member of WIPO. See https://www.wipo.int/export/sites/www/patent_register_portal/en/docs/gcc.pdf
} 
(20\%), China (19\%), Korea (11\%), and the United States (9\%) (WIPO 2018). Most of the other systems rely on them for the search process and follow them in a number of other areas.

Patents are valuable only if they can be enforced and this fact has a number of implications for their use. First, the ability of the courts to reach the 'correct' verdict with respect to infringement and validity will matter; in situations or jurisdictions where there is a great deal of uncertainty about the outcome, and even if both parties agree as to the merits of the case, it may be worthwhile for one or both of them to pursue the issue further or in some cases, to reach a private financial settlement to avoid a random outcome in the courts. ${ }^{7}$ Second, the costs of litigation will matter: parties with deep pockets can threaten those with less access to financial resources, or where the opportunity cost of devoting attention to a patent suit is high, as in small entrepreneurial firms. On the other hand, smaller parties with little to lose can also hold up firms with large sunk investments at risk (Hall and Ziedonis 2001, Lemley and Shapiro 2007, Shapiro 2010). Finally, the threat of litigation may discourage firms from even entering certain areas, thus providing a disincentive rather than an incentive for R\&D. Lerner (1995) documented this phenomenon for biotechnology and Hall et al. (2015) for UK technology firms.

The degree to which these kinds of threats matter depends to a great extent on the costs and extent of litigation, both of which tend to be higher in the United States than in many other countries. However, there are signs that concerns about litigation cost have been increasing elsewhere, notably in Europe, where there has been active debate over the proposals to reduce enforcement costs by creating a supranational patent (the Unitary Patent) and patent court system. This Unified Patent Court was negotiated as an intergovernmental treaty in February 2013 by 25 EU member states, excluding Spain, Poland, and Croatia. At the time of writing, all conditions for its existence have been met, except for ratification by Germany. ${ }^{8}$

\section{Some facts}

WIPO maintains a number of statistics that allow us to get a broad picture of patenting around the world. They collect the number of applications each year from the participating offices, distinguishing being those filed by residents and by non-residents; the latest year of data available is currently 2018. Figure 1 shows the trends during the past 3 decades in total filings, unique invention filings, ${ }^{9}$ and filings at the top 5 IP Offices. ${ }^{10}$ During this period,

\footnotetext{
${ }^{7}$ See Farrell and Shapiro (2007) for detailed models of this process.

${ }^{8}$ See https://www.epo.org/law-practice/unitary/upc/upc-faq.html for further information about the unitary patent and court.

${ }^{9}$ Unique invention filings count a family of filings only once, where a family is defined as a set of filings that share a priority patent.

10 These offices are the US Patent and Trademark Office (USPTO), the European Patent Office (EPO), the Japanese Patent Office (JPO), the Korean Intellectual Property Office (KIPO), and the Chinese Intellectual Property Office (SIPO, renamed CNIPA in August 2018).
} 
filings and invention filings have both more than tripled, while the filings at the top 5 offices have increased over five times.

\section{Figure 1}

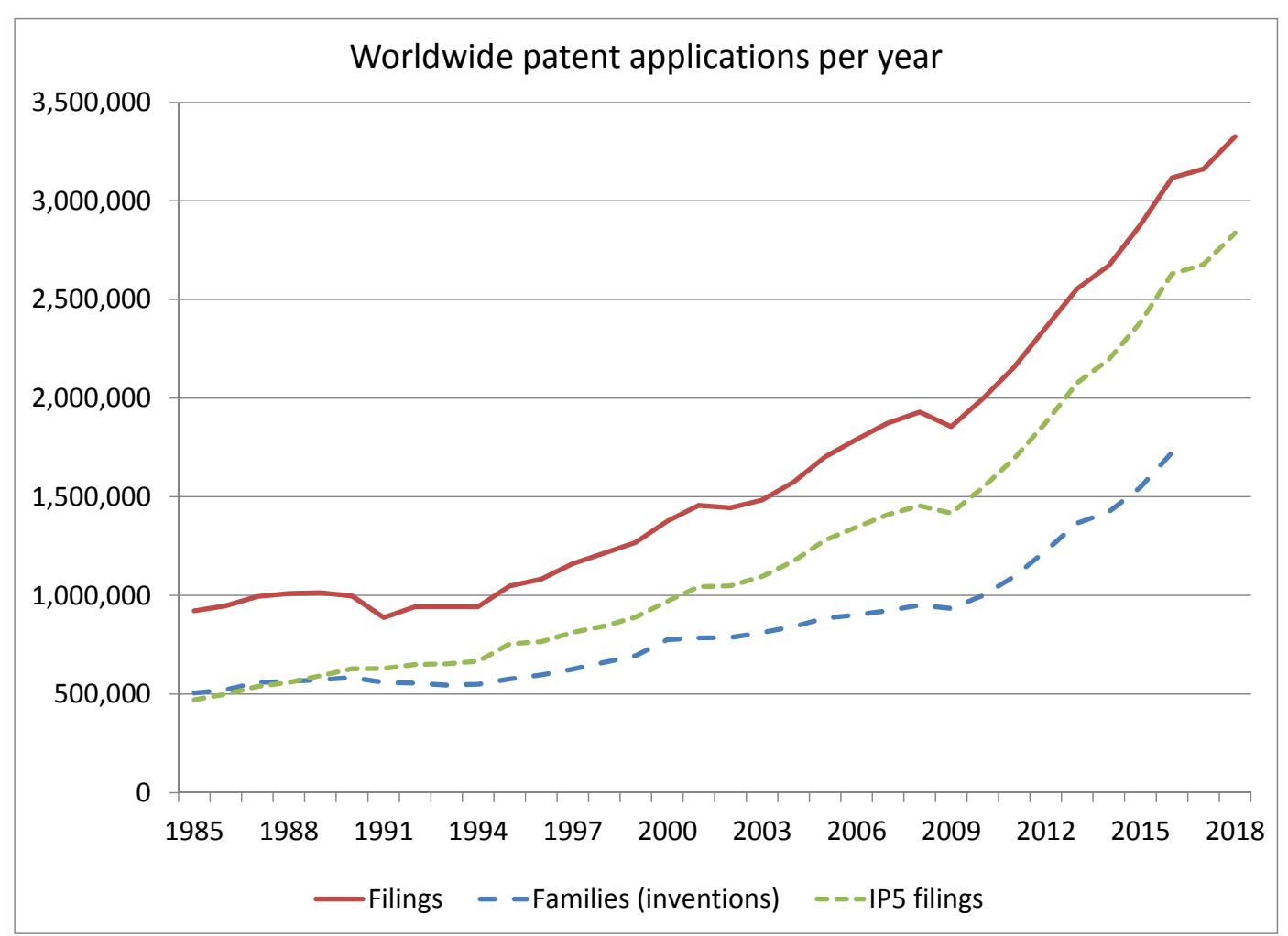

Source: Author's computations from WIPO statistics at http://www.wipo.int/ipstats/en/

Figure 2 shows that the primary reason for the large increase in top 5 filings is the growth of applications at SIPO (CNIPA) from a base of essentially zero to 1.6 million applications, although the US applications have also grown fivefold. Note that the Japanese data are somewhat noncomparable over time, due to the one claim per patent rule that was changed to allow multiple claims in 1988 , leading to a slower growth rate in patenting at that office. 
Figure 2

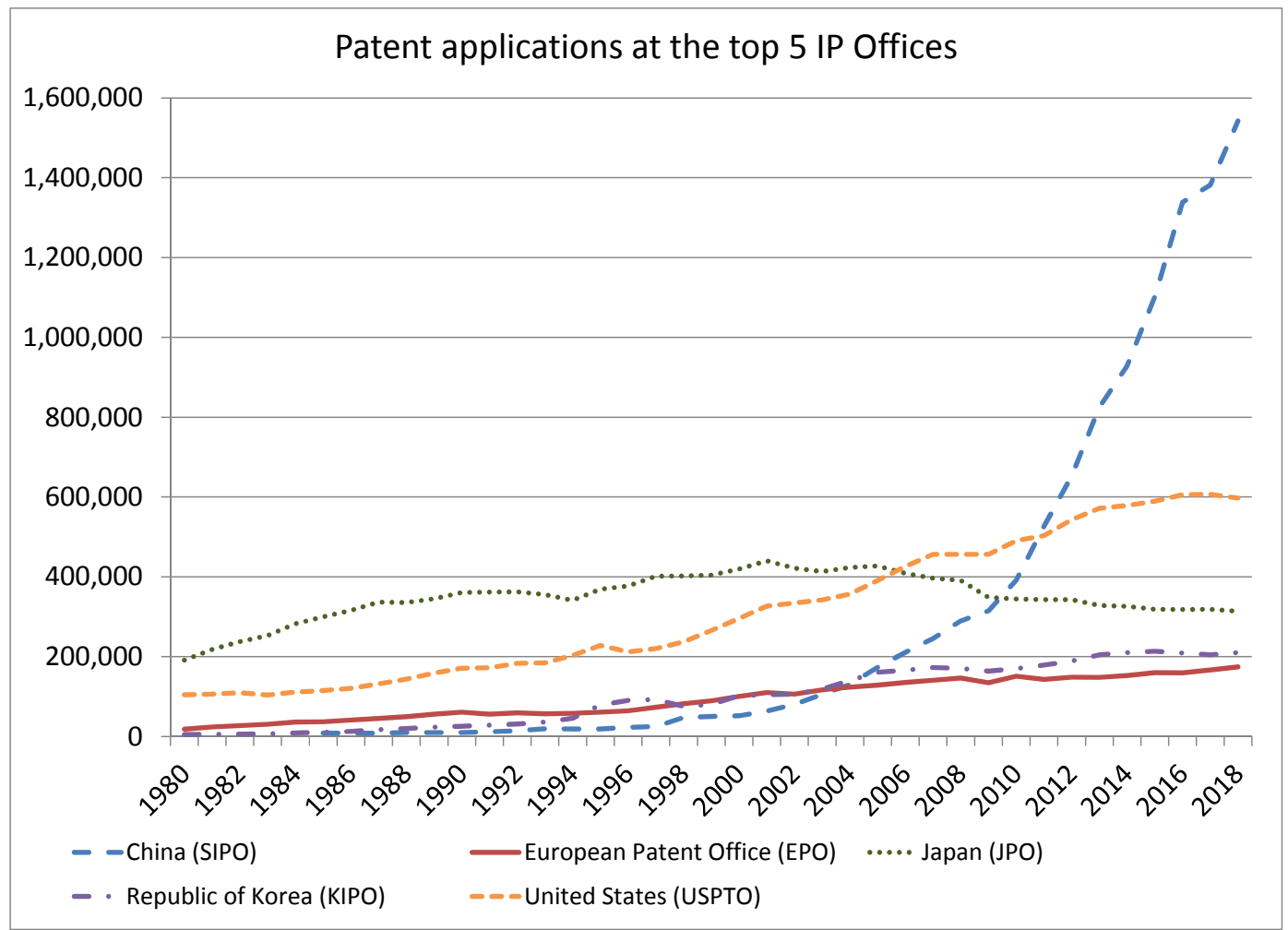

Source: Author's computations from WIPO statistics at http://www.wipo.int/ipstats/en/

In principle, the separation of application counts into those from residents and nonresidents allows an examination of the extent to which a country's patent system benefits local inventors. However, these statistics count an applicant that is a subsidiary of a multinational corporation with a local address as a resident of the country, so they are not really suitable for evaluation of the patenting behavior from local firms. An alternative is to count the filings from inventors resident in the country, but this number is not easily available in aggregate form from the WIPO statistics.

Figure 3 attempts to give some insight into domestic patenting shares around the world, but it also reveals these difficulties in counting local applications. It shows the PPP-adjusted real GDP per capita in 2011 US\$ versus the resident share of patent filings in 2017. European countries tend to have high resident shares, reflecting the pattern of US, Japanese, and other multinationals to apply from their European subsidiaries. In contrast, the Latin American countries tend to receive many more applications from abroad. Within Europe, Israel and Malta have much lower resident shares, whereas within Asia, China, Japan, and South Korea have much higher resident shares than the other Asian countries. Simple descriptive regressions of the resident share on population and GDP and region dummies show that the variation in resident shares is dominated by regional effects. These regressions also show that controlling for GDP and population, resident shares for all other regions are much lower than those in Europe and that Latin America and Oceania have the lowest resident shares. 


\section{Figure 3}

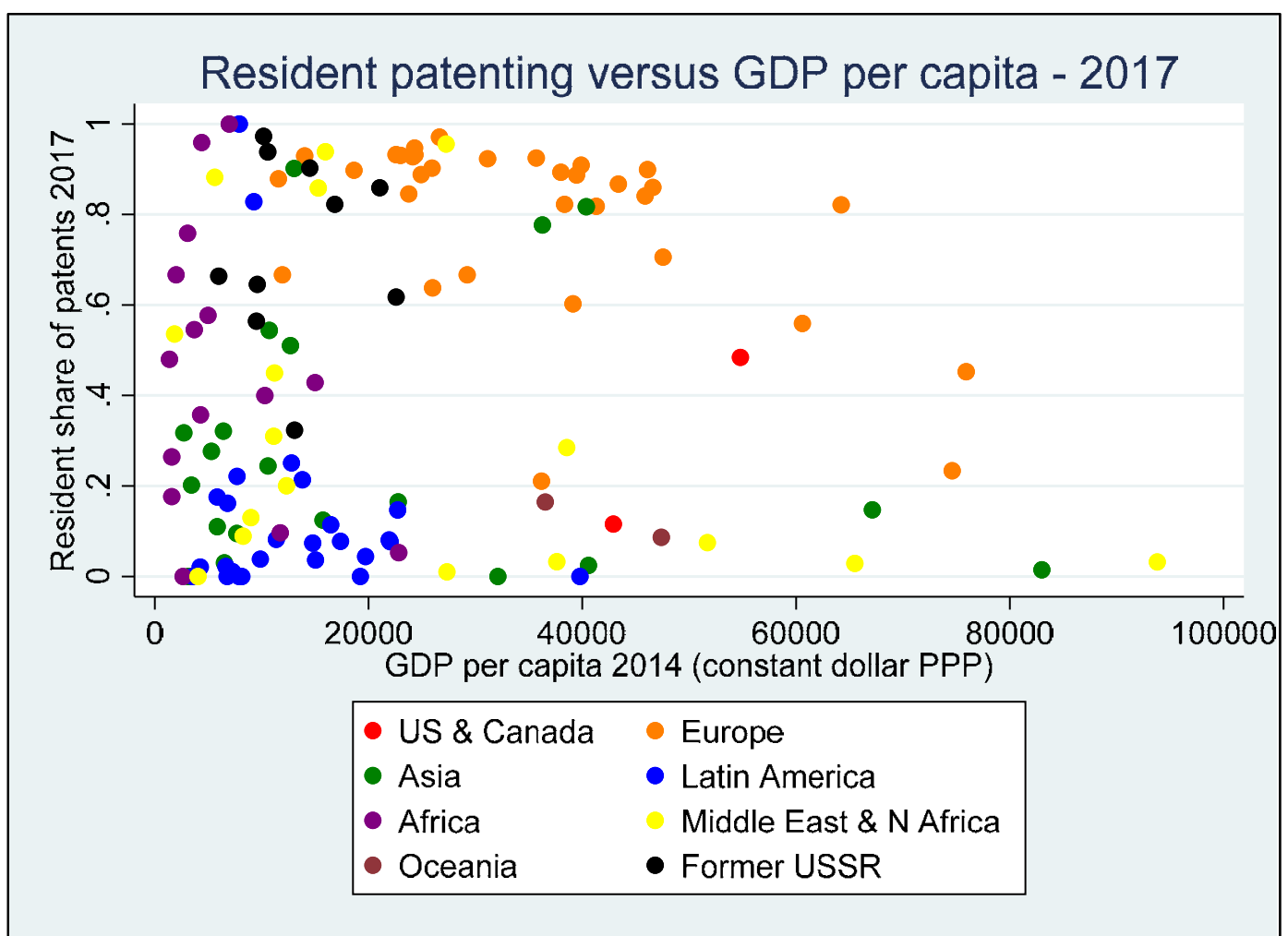

Source: Author's computations; Penn World Tables 9.1 (Feenstra et al. 2015); WIPO statistics

A final point about the use of IP around the world is that essentially all IP royalties are received by high income countries, and most are paid by the same countries. Figure 4 below, drawn from Neubig and Wunsch-Vincent (2017), shows the shares paid by and received by countries at various levels of development. Note that the middle income share of payments has increased from $9 \%$ to the $16 \%$ shown since 1991, due both to their increasing share of worldwide income and the increasing use of multinational patents to secure revenue in those countries. 
Figure 4: Charges for the use of IP by country income class

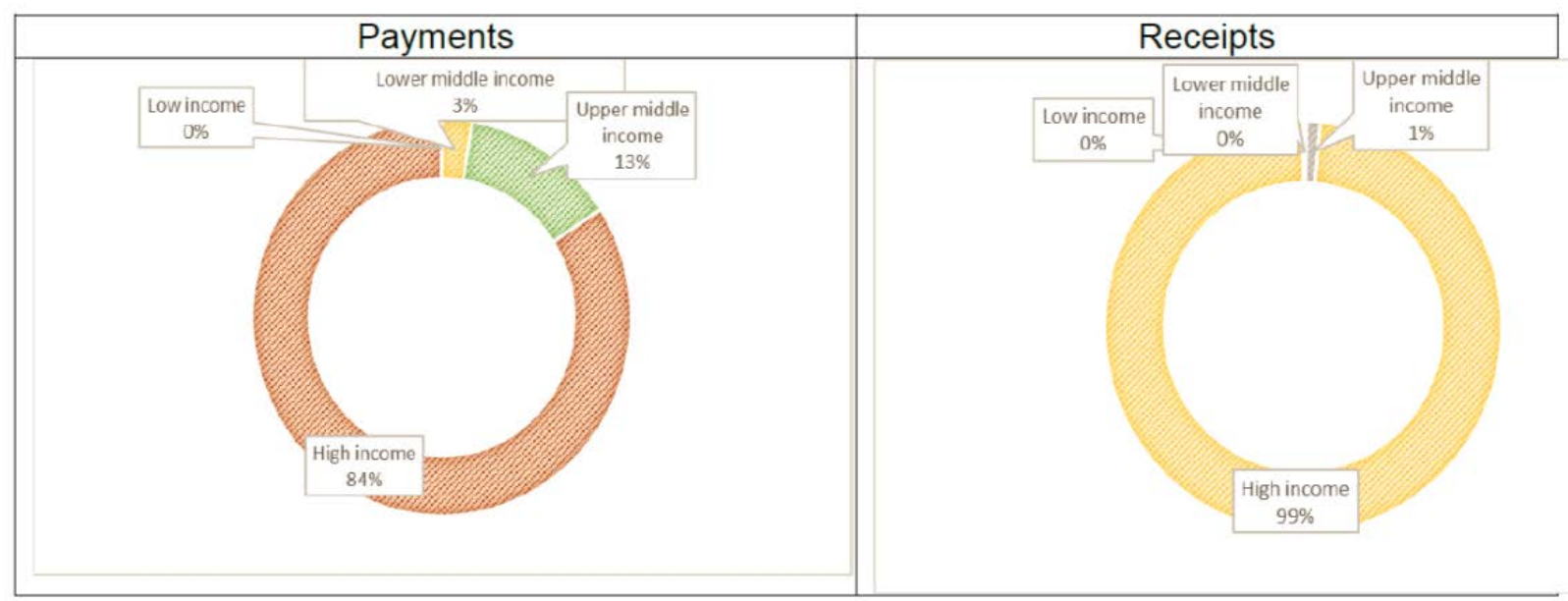

Source: Neubig and Wunsch-Vincent (WIPO), based on World Development Indicators, updated $02 / 01 / 2017$

\section{Patents and innovation}

A longstanding question in the economics of patents is whether the existence of a patent system is beneficial for innovation. A large body of work has explored this question and a few conclusions have emerged. First, introducing or strengthening a patent system (lengthening the patent term, broadening subject matter coverage or available scope, improving enforcement) unambiguously results in an increase in patenting and also in the use of patents as a tool of firm strategy (Lerner, 2002; Hall and Ziedonis, 2001). Second, it is much less clear that these changes result in an increase in innovative activity (Lerner, 2002), although they may redirect such activity toward things that are patentable and away from those that can be kept secret within the firm (Moser, 2005).

A third finding from the empirical literature is that if there is a beneficial effect on innovation from patents, it is likely to be centered in the pharmaceutical, biotechnology, and medical instrument areas, and possibly specialty chemicals. This conclusion relies mostly on survey evidence from a number of countries which shows rather conclusively that patents are not among the important means to appropriate returns to innovation, except in such industries (Mansfield, 1986; Levin et al., 1987; Cohen et al., 2000; Arora et al., 2001). One plausible explanation for this finding is that chemicals naturally lend themselves to clear codification due to the widely accepted system of notation for chemical compounds. This is obviously somewhat an oversimplification, as many patents in these areas do not rely exclusively on a chemical formula, but broadly speaking this fact does make such patents clearer as to their boundaries and somewhat easier to enforce.

Fourth, the relationship between the strength of a domestic patent system and domestic innovation activity may be U-shaped, with domestic innovation falling at first as patent rights are strengthened, and then rising again for developed economies with high levels of the patent rights index. 
Fifth and finally, the existence and strength of the patent system affects the organization of industry, by allowing trade in knowledge, which facilitates the vertical disintegration of knowledge-based industries and the entry of new firms that possess only intangible assets (Hall and Ziedonis, 2001; Arora et al., 2008; Arora and Merges, 2004). The argument is that, by creating a strong property right for the intangible asset, the patent system enables activities that formerly had to be kept within the firm because of secrecy and contracting problems to move out into separate entities. Although limited, research in this area supports this conclusion in the chemical and semiconductor industries.

\section{Patents, innovation, and development}

Historically patent systems have developed in response to a perceived need by governments and inventors to protect their creative and inventive endeavors. In the early days they were often a method of patronage that costs the ruler little but benefitted those he or she wished to reward. In other cases, they were designed to attract craftsmen to a particular city or region (Machlup and Penrose 1950; David 1994; Moser 2013). After the French and American revolutions, patent systems democratized - no longer the prerogative of a king or ruler, now anyone with an invention could apply to have the right to exclude others from practicing it.

Nevertheless, the timing of patent system introduction and/or strengthening does seem to have been coincident or even after industrial development rather than preceding it. E.g., in the $18^{\text {th }}$ and $19^{\text {th }}$ century UK, Mokyr (2009) expresses skepticism that patents were essential during the industrial revolution given the costly features of the system and the fact that a number of successful inventors made no use of it. US industrial development during the $19^{\text {th }}$ century does seem to have benefitted from patents, although this development took place prior to the international patent harmonization of the Paris Convention and US inventors probably found the route to a patent easier than foreign inventors. A modern day example is China, which introduced its current patent system seven years after Deng Xiaoping adopted the Open Door Policy in 1978, amended it several times during the next two decades, and then revised it comprehensively as part of the National Intellectual Property Strategy in 2008.11 This revision recognized the fact that imitation was no longer a viable strategy as China moved to the technology frontier in some areas. Thanks to TRIPS, in many countries the sequencing of development via imitation and then instituting stronger patent systems is no longer possible, raising again the question of whether the one-size-fitsall approach is ideal for development and innovation in developing countries.

How do developing countries catch up? That is, what are the ways they can learn in order to close the knowledge gap? One channel is clearly the mobility of research and other skilled workers, as well as public resources such as scientific journals, the internet, and international patents. None of this is greatly affected by the presence of a domestic patent system. A second channel is the purchase of investment goods embodying new innovations, imitation and reverse engineering, licensing of patented technologies and technology

${ }^{11}$ http://www.wipo.int/wipo_magazine/en/2010/06/article_0010.html 
information from foreign innovators, direct technology transfer by multinational corporations to their subsidiaries, and potential spillovers from those subsidiaries to domestic firms. This latter channel is likely to be sensitive to the presence of a functioning domestic patent system.

Willingness to transfer technology in the form of investment goods, licensing, and knowhow to both domestic firms and multinational subsidiaries is likely to be affected by the protection offered by the local patent system, whereas learning by imitation and the acquisition of technology spillovers by local firms may be inhibited by the use of the patent system by those generating spillovers. This line of reasoning suggests that there are at least two separate but related questions whose answers may be somewhat at odds with each other when considering patent policy. The first is whether stronger patent protection in a host country encourages technology transfer to that country. In particular, how does the presence of patent protection affect the behavior of foreign firms that may potentially invest in the country, sell technology to firms in the country, or form joint ventures with domestic firms? The second question is whether stronger patent protection encourages technology development in the country itself. That is, how does it affect the behavior of domestic firms? The first question has been easier to answer but the second is probably more important for the development of the country in question.

With respect to the first question, a priori it seems clear that stronger IP protection in the host country should encourage (or at least not discourage) the transfer of technology by foreign firms to their subsidiaries and possibly to domestic firms, either via partnership or simple sale or licensing. Note that this argument presumes that the intellectual property rights are enforceable, which is not an innocuous assumption. Also, note that such transfer may or may not help the local development of innovation skills and human capital. With respect to the second question, it also seems clear that stronger IP protection could encourage the innovative activities of domestic firms, but that such protection could also discourage learning via imitation and therefore inhibit technological catch-up. Thus the impact of IP systems on technological development is ambiguous and requires further investigation.

\section{Technology transfer and the patent system}

International technology transfer typically takes place via trade, foreign direct investment, joint ventures with local partners, or simple technology licensing, although in the latter case, some tacit knowledge probably also needs to be transferred. In all of these cases, foreign firms run the risk that imitation by local firms may erode some of their profits from these activities, so the presence of enforceable IPRs should encourage all these activities. In fact, Edith Penrose goes as far as to argue that for developing countries "the only economic advantages to be gained from granting foreign patents lies in the possibility that in one way or another such grants will induce the introduction of foreign technology and capital" (Penrose, 1973: 770). Obviously, in the cases of more advanced technology, the imitation risk is highest when the host country has the capacity to adopt and develop such technology, which implies that the risk is generally greater in middle income countries than 
in low income countries. This risk is further increased, if technologies require local adaptation in order to fit local needs and regulatory requirements and standards. At the same time, if IPR protection is strong, foreign firms may prefer to license technologies instead of choosing to be a local presence, which could decrease the amount of technology transferred. This decision may also be influenced by the ability of foreign firms to enforce license contracts. However, it is also conceivable that stronger IPRs increase the incentives for firms to exploit IPRs themselves instead of licensing out. It is likely that these relationships differ by industry and type of activity, i.e., manufacturing or distribution.

There is some empirical evidence on the trade effects of strengthening IP laws, which suggests that they do indeed have an impact. For example, Maskus and Penubarti (1995) increasing patent protection had a positive impact on manufacturing imports into developing countries that was higher for the larger of these countries. Ivus (2010) used data on exports from developed to developing countries over the period that TRIPS was introduced to show that strengthening patent rights increased high-tech exports to developing countries by about 9 per cent.

In Hall (2014), I reviewed the empirical literature on the relationship between patent systems and technology transfer via trade, foreign direct investment (FDI), and technology licensing. ${ }^{12}$ The trade literature suggested that the strength of country's IP system did affect the willingness of developed countries to export manufacturing goods, especially of the country in question had imitative capacity. The FDI literature, which is older and more voluminous, found a positive correlation between FDI and domestic patenting by MNCs as well as a correlation of FDI with the strength of IPR enforcement.

Looking specifically at foreign investment in R\&D, Thursby and Thursby (2006) surveyed 200 R\&D managers from Western European and US multinationals, asking about the factors affecting their choice of location for a new laboratory, distinguishing between location in developed and emerging economies. The most important factor in an emerging economy was its growth potential. However, they found that good IP protection was important in both types of country, ranking only slightly below the factor with the highest importance, the availability of qualified R\&D personnel. This result certainly suggests that IPRs will facilitate some technology transfers to middle income countries.

In summary, the literature indicates a positive correlation between FDI and the level of IPR enforcement. Considering the extensive evidence on FDI serving as a channel for technology transfer, this implies a positive relation between IPR enforcement and technology transfer through the channel of FDI. However, the literature also points to other important factors in attracting FDI, such as country risk and the availability of low-cost high-skilled labor. It also generally emphasizes the importance of absorptive capacity in whether patents will affect technology transfer. That is, if there is no ability to imitate in the destination country, patents will not matter as much to the firm deciding on investment strategies in that country.

${ }^{12}$ See also Maskus (2004) and Branstetter (2004) for earlier reviews of this literature. 


\section{Domestic innovation and the patent system}

The results on IP and technology transfer seem sensible and consistent with a priori intuition. However, as suggested earlier, the more important question for policy is the question of the impact of strengthened IPRs on innovation and development within a developing country. Does stronger patent protection help to enable and increase that country's own innovative capacity? This question has been approached empirically by economists in two different ways: looking at the relationship between IP and innovation across countries, as described earlier, and using individual country case studies of changes in patent law. For example, Kim (2003) argues that the Korean case shows that strong IPR protection in earlier stages of industrialization can hinder learning via imitation. Kumar (2003) reviews the historical relationship between IPRs, technology, and development in East Asia and concludes that "Japan, Korea, and Taiwan have absorbed substantial amount of technological learning under weak IPR protection regimes during the early phases." (Kumar 2003: 217).

There is a good-sized literature on patents or IP and economic growth using cross-country regression, pioneered by Ginarte and Park (1997). Gold, Shadeed, and Morin (2017) review the results from this line of research, finding them somewhat inconsistent, especially as concerns the variation in the relationship with the country's income level. As they suggest, some of this inconsistency can be due to the use of different models and data choices, and they construct a new IP index that is sensitive to the many changes induced by TRIPS. They then advance the interesting hypothesis that the IP-growth association is due to a placebo effect: foreign investors believe that IP strength is good for their investment so when they see it increase, they increase their investment even though there is no actual impact of IP strength on the investment success. This hypothesis is supported by their evidence that the impact of IP-intensive imports on growth is many times that of the effect of IP on growth through domestic inventive activity (US patent applications from the country) in lower and upper middle income countries, controlling for the strength of IP. They also find that the attractiveness of a country as a PCT destination is not related to growth, in the presence of their IP strength index. Although it is not possible to truly test for the placebo effect, the finding that technology transfer rather than domestic invention is more induced by IP strength seems consistent with what other researchers have observed.

\section{Recent research on patenting in middle income countries}

I now turn to a closer look at what we have learned from recent research on the strengthening of patent systems in middle income countries, some of which has been TRIPS-induced. Research by my co-authors and myself has looked at the introduction of a broad regional system in the presence of existing national systems, the impact on firm performance from the introduction of a reformed patent system, and finally on the specific impact of patents on pharmaceutical innovation and patenting in developing countries. 


\section{Regional patent systems ${ }^{13}$}

Operating a patent system that does full search and examination is an expensive undertaking, and may not be the best use of government spending in many countries. The PCT system described earlier is a partial solution to this problem. In addition, there are a number of regional patent systems that serve more than one country, such as the Organisation Africaine de la Propriété Intellectuelle (OAPI) for French-speaking Africa, the African Regional Intellectual Property Organization (ARIPO) for English-speaking Africa, and the Eurasian Patent Organization (EAPO) for Russia and the former Soviet republics. The most important regional system is undoubtedly the European Patent Convention (EPC), covering about 40 European countries, Do such systems reduce patenting costs for their participants? Do they induce more patentable invention?

Helmers and I (2018) explored these questions in a study of accession to the European Patent Convention (EPC) by a number of mostly Eastern European countries during the 2000-2008 period. We looked at changes in patenting behavior around the time of accession by non-residents, residents, and the inventors and firms resident in the country.

The EPC was created in 1977 with 7 countries; it now has 41 contracting states and 6 countries as extension states that allow validation of European patents in their country. ${ }^{14}$ The applicant makes a single application to the European Patent Office (EPO), designating the states in which the patent might be validated. After grant, the patent must be validated (and renewal fees paid) in every state for which coverage is desired. Enforcement takes place in national courts. ${ }^{15}$ In principle, obtaining a European patent is lower cost than applying at each national office if coverage is desired in more than one or two countries. Other regional systems also use this model.

The 14 countries we studied are shown in red in Figure 5. With the exception of Norway and Iceland, they are classed as middle income countries, in contrast to most of the other members of the EPC, which are high income. Using patent data at the EPO and at the national offices of the 14 countries, we examined the changes in patent application strategies in these countries and at the EPO around the time of accession to the EPC. We also looked at any changes in FDI in the countries in response to accession.

\footnotetext{
${ }^{13}$ This section is based on joint work with Christian Helmers. See Hall and Helmers (2019) for details.

14 These countries are Bosnia and Herzegovina, Montenegro, Moldovia, Tunisia, Morocco, and Cambodia.

15 The Unitary EU patent (currently for approximately 25 European countries) comes into force in 2018. This patent will have a single set of fees and enforcement will take place at the Unitary Patent Court. Our analysis preceded the introduction of the unitary patent by several years.
} 


\section{Figure 5}

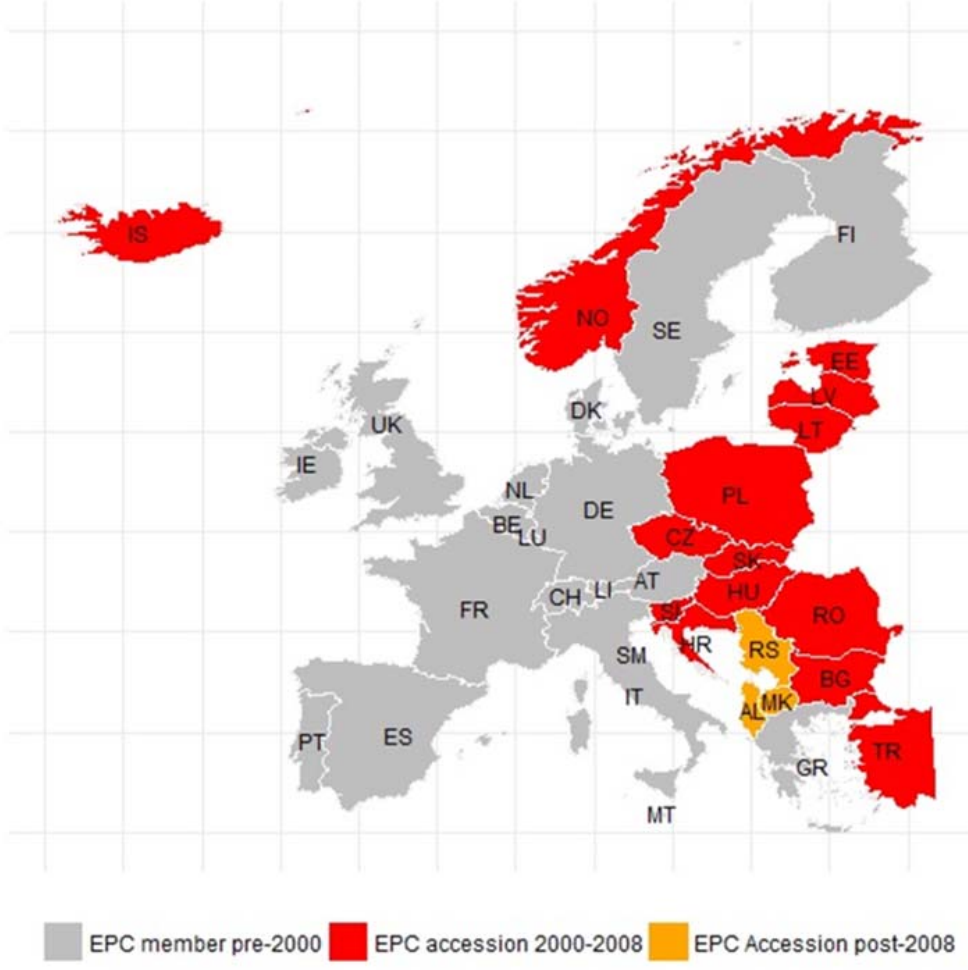

Our findings were that resident applicants hardly respond to accession, in the sense that they continue to apply to their national office, only occasionally adding an application to the EPO. There was a small response via increased EPO patenting by inventors resident in the countries. In contrast, non-resident applicants respond strongly to accession, as one might have expected, immediately switching their patent applications to the EPO. However, there was little visible change in the willingness of foreign firms to invest in the country, although overall there was growth in FDI before and after accession. We cautioned that the accession of Eastern European countries may be a special case, because many of these countries were in the process of joining the EU at the same time, and investment may have been responding to this fact.

The main conclusion from this study was that non-resident applicants and inventors benefitted from a reduction in the cost of obtaining broader coverage, but that resident inventors were affected very little by the shift. This suggests that they may not have viewed their inventions as valuable or novel enough to justify the expense of dealing with a remote office in a different language. Nevertheless, given the fact that non-resident applicants outnumber residents by approximately threefold, there was a substantial reduction in the costs born by the national offices, as these applicants shifted their applications, which may be by itself a benefit to the country in question. 


\section{Study of Chilean IP use and firm performance ${ }^{16}$}

How do firms in a rapidly developing country make use of IP and does it impact their performance? Fink, Helmers, and I (2018) looked at this question using a comprehensive panel of Chilean manufacturing firms and their IP holdings. Chile is an interesting case because of its relatively rapid growth after the end of the military dictatorship in 1989, when it transitioned from a middle to high income country by the World Bank definitions. Among other changes, this transition to democracy was closely followed by the introduction of a new intellectual property system. In the mid-1980s, 70 countries had a higher real GDP per capita than Chile, whereas by 2014, there were only 57 such countries (see Figure 6 below). In 2010, Chile became the first South American member of the OECD.

\section{Figure 6}

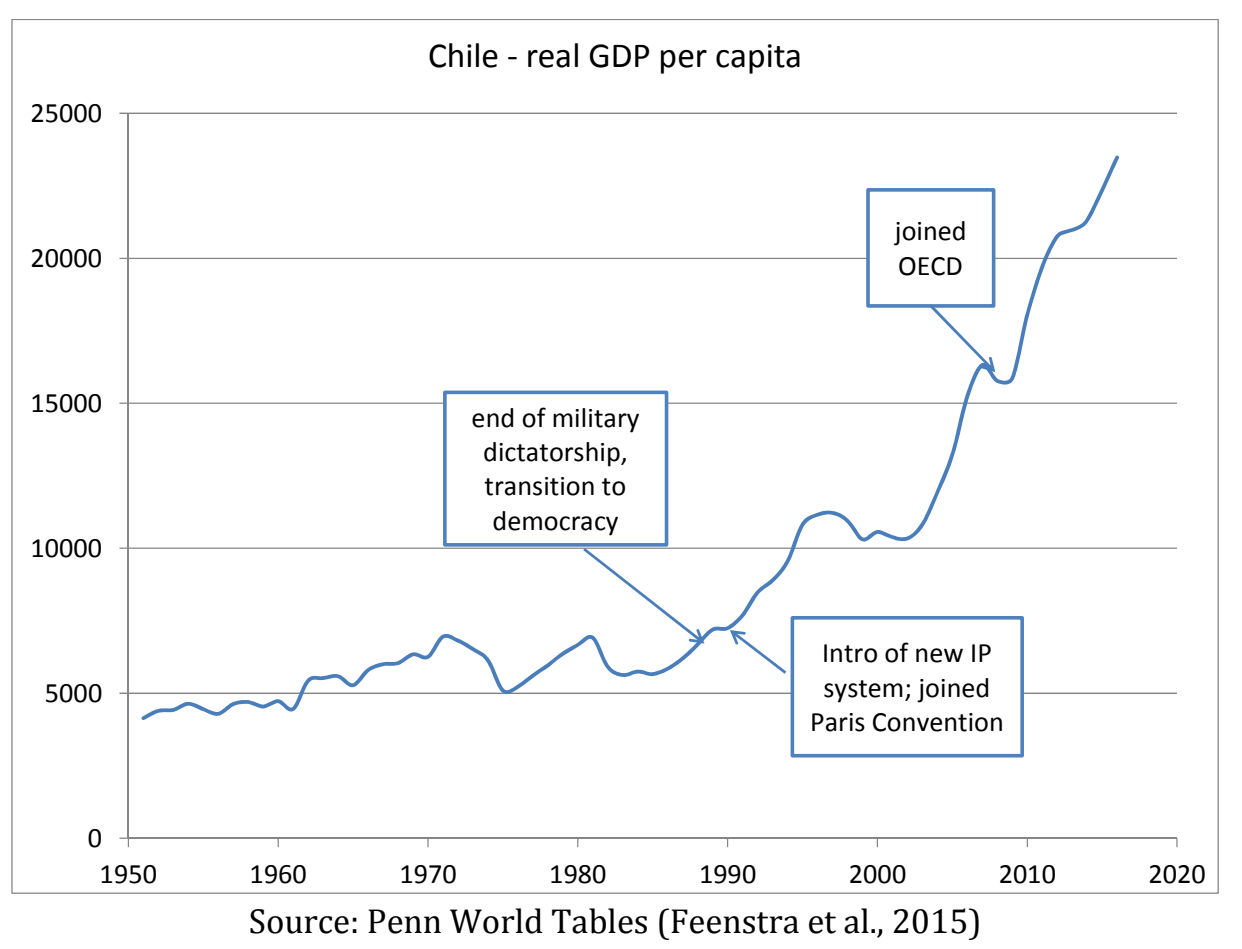

Because Chile introduced a new IP system and joined the Paris convention in 1990/1991, it is useful to study how these changes impacted firms in Chile. Therefore a joint project of WIPO and INAPI (Chilean National Institute of Industrial Property) was undertaken to construct a dataset combining Chilean patents, trademarks, and design rights between 1991 and 2010, the ENIA manufacturing census 1995-2005, and the Innovacion surveys 19971998, 2000-2001, 2003-2010 (Abud Sittler et al. 2013). In Fink et al. (2020), we used these data to look at whether there was any impact on firm growth or productivity following their first time using the IP system. Because we do not have manufacturing sector data prior to 1991 , it is not possible to treat the introduction of the new IP system as a natural experiment, analyzing firm behavior before and after its introduction. In any case, given all

16 This section draws from joint work with Carsten Fink and Christian Helmers (Fink et al., 2020). 
the other changes to the macro-economy at the same time, this would not be a useful procedure. Our approach is to compare firms that use the system for the first time some time post 1991 to those that do not use it during the 1991-2005 period. Obviously, this does not remove all concerns about endogeneity of use, but it still turns out to be somewhat revealing.

The most striking thing in these data from our first look was that most Chilean patents are filed by non-residents ( $~ 90$ per cent over the 1990-2010 period), whereas the majority of trademarks are filed by local applicants ( $\sim 70$ per cent over the same period). This finding suggests that even in middle income countries, the first consequence of aligning a patent system to international standards is that it facilitates the extension of patent protection by multinationals, rather than inducing indigenous patentable innovation. In contrast to patents, trademarks in many cases require only distinctness within the country in which they are registered, so may be easier for domestic firms to obtain and will provide some protection against imitation of innovative products that are not eligible for patent protection. Note also that Chile does not have a use requirement for trademarks, which has led to considerable "squatting" by domestic entities on internationally known trademarks (Fink, Helmers, and Ponce 2018).

We found that the determinants of both patent and trademark use are similar to those in developing countries (Hall et al. 2013 for the UK; Balasubramanian and Sivadasan 2011 and Arora et al. 2016 for the US). Firm size (in terms of employees), market share, whether it exports, and being located in the Santiago metropolitan area were positively associated with both. Controlling for these variables, foreign owned firms were more likely to patent and less likely to trademark, consistent with the aggregate statistics, and publicly owned firms do not trademark much, although they are slightly more likely to file for patents.

We then examined the performance impact of first time IP use during the 1995-2005 period, using difference-in-difference methodology to compare revenue, inputs (employment, capital, and materials), and TFP (Total Factor Productivity) between those who do not use a particular form of IP and those who file for their first IP of a particular type (patent, trademark, or design right). We used a variety of estimates for TFP, finding that the Ackerberg-Caves-Frazier method was preferred, although the results of the diff-indiff estimation did not depend strongly on the choice of the TFP estimator. We found fairly striking results for all types of IP: the "treated" firms grew faster both before and after first time IP use, but TFP was unaffected by the adoption of IP. We show the results for patents graphically in Figure 7 below. There is substantial firm growth before first time use that then flattens out, with a hint of increased TFP two years after the first patent filing. Because patenting samples are small, and changing over the period, this rise did not translate into anything significant in the diff-in-diff regressions. 


\section{Figure 7}

\section{Trends for first-time users of patents (relative to controls)}

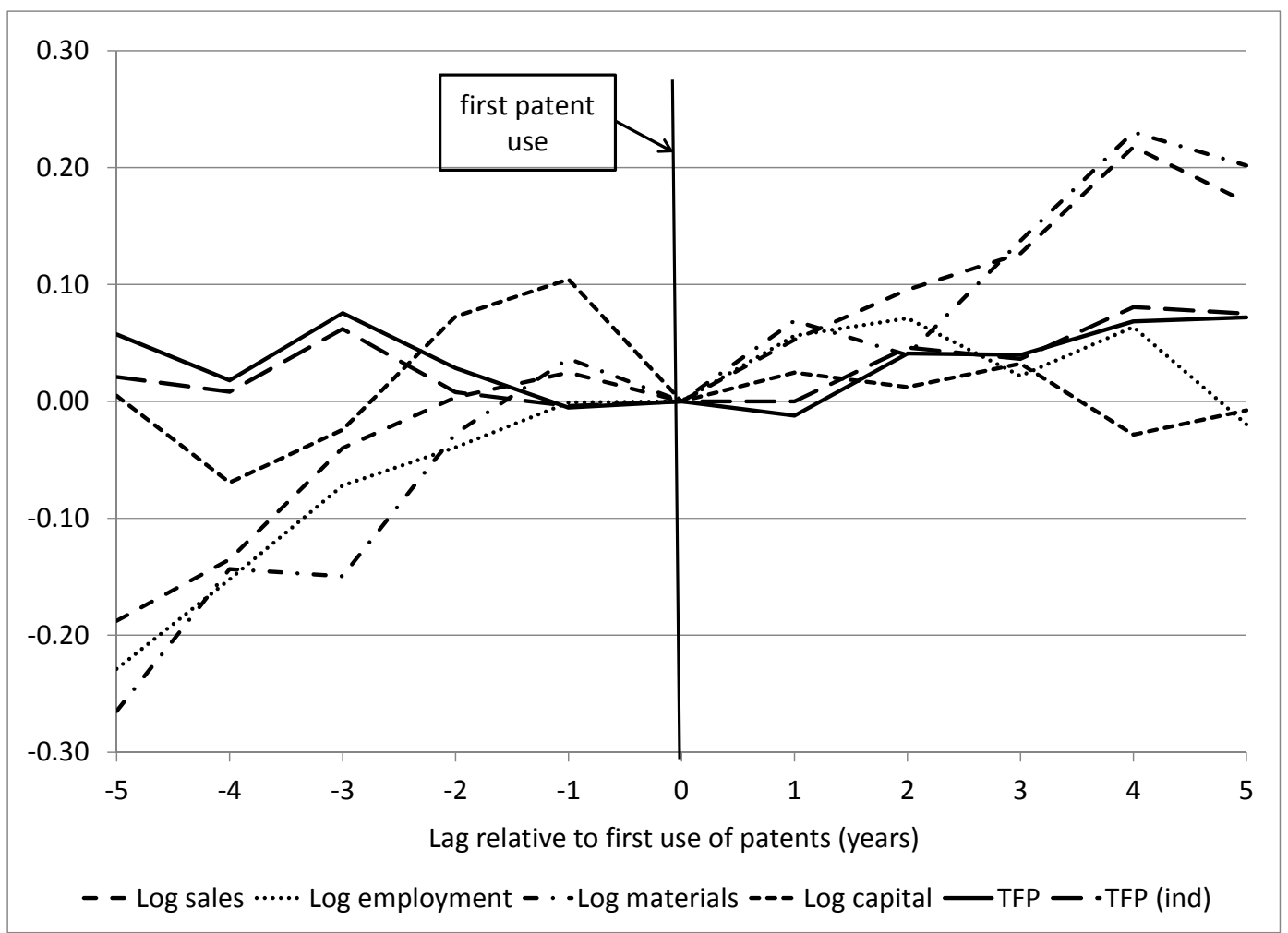

Source: Fink, Hall, and Helmers, 2020.

As a final piece of evidence on Chilean domestic inventive activity, I show the evolution of Chilean origin patenting worldwide in Figure 8. The figure shows Chilean origin patent applications via the direct and PCT route, at all offices worldwide, separately for INAPI (Chile), the IP5 offices (CNIPA, EPO, JPO, KIPO, and USPTO), and the other offices, most of which are those of the higher income Latin American countries. It is clear that Chilean inventors do not file internationally in any appreciable numbers until quite late in our sample, around 2002, 10 years after the country joined the Paris Convention. This suggests that there can be a considerable lag between the introduction or strengthening of an existing patent system and its effects on domestic invention, which in turn helps to explain why we frequently do not see any impact in short panels. 
Figure 8

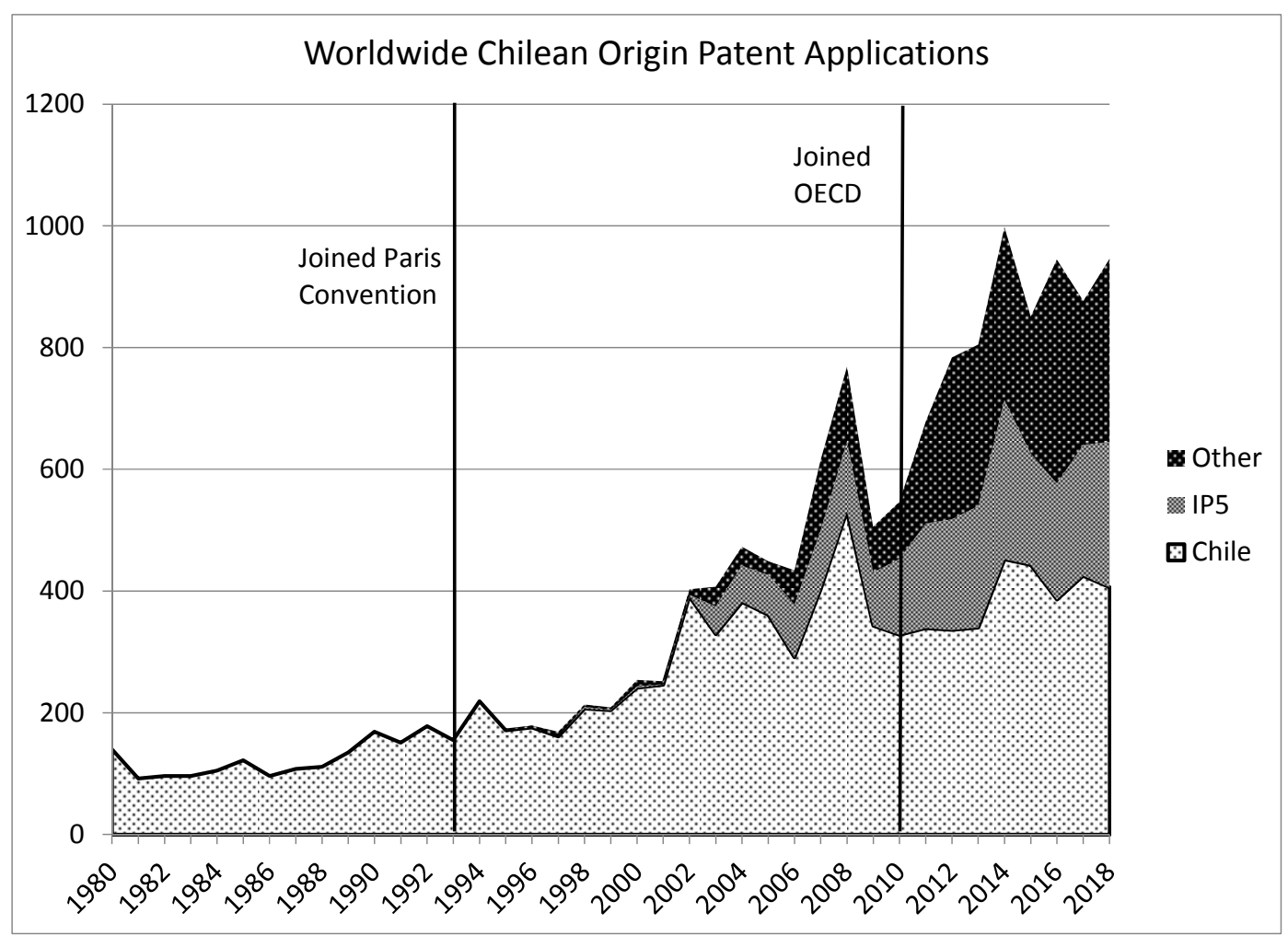

Source: http://www3.wipo.int/ipstats/

Our conclusions from this study of IP use by Chilean firms can be divided into two parts: those that represent differences from most developed countries, and those that are the same. The differences from the use of patents in high income countries are that most patents come from outside the country and that foreign-owned firms are much less likely to do R\&D in the country. The similarities to developed countries are that there is heavy trademark use by domestic firms and individuals, and the relationship of R\&D and innovation to firm characteristics is very similar, even though the absolute levels are lower (Abud Sittler et al. 2013, Fink, Hall, and Helmers 2018).

\section{Patents and pharmaceutical innovation in Chile ${ }^{17}$}

Much of the debate over the role of patents in developing countries has centered on their use in covering pharmaceutical innovations. The weight of evidence in developed economies suggests that these patents are the most valuable for firms (Hall et al. 2005, Arora et al. 2008) and the most highly valued by managers (Cohen et al. 2000). Correspondingly, this technology is often the technology where multinationals choose to extend their patenting activity into developing countries, inhibiting the development of cheaper generic alternatives in those countries that have the relevant technological capacity

17 This section draws from joint work with Maria Jose Abud Sittler and Christian Helmers (Abud Sittler et al., 2015). 
(Lanjouw 1997; Scherer and Weisburst 1995). It is also often argued that patent protection in developing countries has the benefit of inducing research into neglected diseases.

Given the often contentious debate around this topic, which affects the health of so many, it is not surprising that a vast amount of research time has been devoted to it. I discuss a few of the recent empirical papers here. The key questions addressed are whether pharmaceutical patent availability increases pharmaceutical innovation, especially for neglected diseases, and whether such availability speeds up the diffusion of drugs to less developed countries from those where they were first introduced. In general, the focus is on pharmaceutical product patents (rather than process patents), because the former were frequently not permitted in a number of countries before TRIPS, whereas the latter were more frequently allowed.

Qian (2007) looks at a broad range of countries over the 1978-2002 period, examining whether R\&D or US patenting increases in the country after product pharmaceutical patent introduction. She uses a sample of 26 such countries matched to controls by GDP, population, education level, IPR strength, legal origin, and previous pharmaceutical industry strength. Regardless of whether the country previously allowed process patents, she finds no increase in domestic R\&D or US patent filings from product patent introduction except at higher levels of GDP per capita. Kyle and McGahan (2009) exploit the variation in timing of the TRIPS introduction of pharmaceutical product patents, 1990-2006. They associate patents to drugs for particular diseases and find a strong association between the introduction of pharmaceutical patents and R\&D effort for diseases that are prevalent in high income countries, but no association for the "neglected" diseases prevalent in low income countries. Thus both these papers are unable to find positive innovation impacts for developing countries from the introduction of pharmaceutical patents.

Turning to the diffusion of drugs that already exist in developed countries, the results are more positive. Cockburn, Lanjouw, and Schankerman (2016) examine 642 new drugs launched in 76 countries during the1983-2002 period. They find that price regulation delays the launch of such drugs, increasing the diffusion lag by 25 to 80 per cent. Longer and stronger product patents speed up launch, with long patents (those with lifetimes 18 years or longer) reducing the lag by 55 per cent. The results for process patents are more ambiguous -- although generally positive for launch, whether the term of process patents increases launch probability depends on the correction for endogeneity of the policy variables. Their results are similar for countries at all income levels.

Kyle and Qian (2014) compare 716 drugs pre- and post- TRIPS compliance in 59 countries in the 2000-2011 period. Like Cockburn et al., they find that patent protection speeds launch, and also that it increases both the price and the quantity of the drug sold. Price discrimination across countries does not depend on whether the drug is covered by a patent, but the price premium for patented drugs declines after compliance with TRIPS. They suggest that policies to mitigate the impact of TRIPS in developing countries, such as price controls, may be responsible for this effect. 
Our paper (Abud Sittler, Hall, and Helmers 2015) focuses on a current policy debate in the pharmaceutical patenting area: whether firms are able to extend the patent life of drugs using secondary patents and how this strategy impacts less developed countries. Secondary patents are those on alternate formulations of the drug or on variations in methods of administration. A number of developing contrives have restricted or considered restricting their use. ${ }^{18}$ In the unsuccessful negotiations over the Trans Pacific Partnership a critical issue was patentability of new uses or methods of using a known product and the "enhanced efficacy of a known product" threshold (Article QQ.E.1). In our paper, we looked at whether foreign pharmaceutical firms use strategic patenting behavior to keep domestic generic producers off the market in Chile. That is, how is entry into the manufacture of drugs for specific therapeutic categories affected by the presence of foreign pharmaceutical patents? Do secondary patents delay entry by Chilean firms into drug production? What is the share of patents held by foreign pharmaceutical companies associated with drugs commercialized on the domestic market?

This debate is encapsulated by the following anonymous quotes by a pharmaceutical company and generic producer in an EU Commission (2009) report on secondary patenting:

"We were recently successful in asserting the crystalline form patent in [name of country], where we obtained an injunction against several generic companies based on these patents by 'trapping' the generics: they either infringe our crystalline form patent, or they infringe our amorphous form process patent when they convert the crystalline form to the amorphous form." An anonymous pharmaceutical company, EC (2009), p. 189.

"The entire point of the patenting strategy adopted by many originators is to remove legal certainty. The strategy is to file as many patents as possible on all areas of the drug and create a 'minefield' for the generic to navigate. All generics know that very few patents in that larger group will be valid and infringed by the product they propose to make, but it is impossible to be certain prior to launch that your product will not infringe and you will not be the subject of an interim injunction." An anonymous generic producer, EC (2009), p. 196.

There is some prior empirical evidence on secondary patents. The same European Commission study found a primary to secondary patent ratio of $1: 7$, with a pending patent radio of $1: 13$, and a granted patent radio of $1: 5$. There were disproportionately more secondary patents after product launch, suggesting that successful drugs garnered more such patents, not surprisingly. Kapczynski et al. (2012) investigated the type of secondary

${ }^{18}$ Some examples: India's Glivec decision, 1 April 2013 - imatinib mesylate (beta-crystalline form of an existing anti-cancer drug) rejected by Supreme Court for obviousness. Brazil - Projeto de Lei $\mathrm{n}^{\circ}$ $5.402 / 2013$ (includes provision similar to paragraph 3(d) of India's Patent Act). South Africa proposed National Policy on IP: "[Legislation] should exclude diagnostic, therapeutic and surgical methods from patentability, including new uses of known products, as is the case under the TRIPS agreement." See Sampat and Shadlen (2017). 
patents associated with drugs filed at the FDA during the 1991-2005 period: $56 \%$ were on formulation, $24 \%$ on salt, crystalline or other forms, and $63 \%$ methods of use (some of more than one type). Secondary patents were filed after FDA approval and extend exclusivity lifetime by an average of 4 to 5 years, with more secondary patents if the branded drug's sales were higher.

Sampat and Shadlen (2017) compared Brazil, India and Argentina to the US, Europe (EPO patents), and Japan. They found little evidence that secondary patent provisions in the former group of countries have had much effect on limiting them, although grant rates overall tend to be lower in those countries, both for primary and secondary patents.

Our study was based on a match of the complete list of drugs and their active ingredients registered at the Chilean ISP (Institute of Public Health) 1934-2012 with the Chilean patent data. ${ }^{19}$ Pharmaceutical patents were not allowed in Chile until the patent reform of 1991, and there has been consistent growth in them since then. The patent law has been amended several times for TRIPS and various free trade agreements, to extend patent life from 15 to 20 years, allow for extension due to delays in grant/registration, and to soften the secondary use restriction.

Our findings were the following: First, only a small fraction of pharmaceutical patents $(<2 \%)$ are held by Chilean entities, and the largest source countries are the US, Switzerland, and Germany. Second, 113 (22\%) of 504 matched patents were primary patents, and primary patents were more likely to have been granted. Third, the top therapeutic classes protected by patents differed depending on the age of the drugs: anti-ulcer, antidepressants, anti-psychotics are older drugs (pre-1991) and have few primary patents if any, whereas anti-virals (including HIV) and anti-neoplastics (anti-cancer) are newer and had a much higher ratio of primary patents, up to 40 per cent of the total.

The ISP register also contain information on the role of firms registering drugs. Chilean firms were largely engaged in domestic manufacturing, quality control, importing, packaging, and distribution. Only two drugs had a Chilean firm as the source, but no patents (both were generics), while two drugs had secondary patents owned by Chilean firms, and no primary patents: Larmax-D, an anti-histamine compound, and Faronkal, a nasal decongestant compound used for sleep apnea.

Our conclusions from this investigation were that Chilean companies manufacture common drugs with lots of different formulations, but they do not manufacture newer drugs that are patent protected. Almost all pharmaceutical patents are held by foreign firms, and almost no products of domestic companies are protected by patents. Looking across therapeutic classes, we found a negative relationship between the share of drugs patented by foreign companies and the number of drugs manufactured by domestic companies. In addition, we found weak evidence for strategic patenting behavior in pharmaceuticals in the form of extending patent life.

${ }^{19}$ This was a complex undertaking; for details on the match and the identification of secondary patents, see Abud Sittler et al. (2015). 


\section{Conclusions}

I began this survey with a quote from Edith Penrose suggesting that the benefits of international patent systems have been overemphasized relative to the associated costs. The preceding overview of the literature on the role of the patent system in economic development suggests that the benefit-cost ratio may be even less attractive in the case of developing countries, primarily because the benefits are low, while the costs are similar to those in developed countries.

There are a number of reasons to think that having a patent system is not an important ingredient of development policy for low or even middle income countries. First, there is the historical cross country evidence of Moser $(2005,2013)$ and Lerner (2002), mentioned earlier. Mostly based on variation within Europe, both authors use innovation measures that are not contaminated by the local patent system to show that innovation activity is not increased by a stronger system.

Second, the introduction of a regional system with broader patent scope geographically does not increase innovative activity in middle income countries and only shifts patenting activities marginally. In general, a very small share of firms in those countries uses the system at all. Third, joining the international Paris Convention and increasing patent strength does not lead immediately to more innovation and patenting, although it is true that the few patenting firms in Chile are faster growing, both before and after their first patent. An interesting suggestion from Gold et al (2017) is that the empirically observed feedback or simultaneity in the relationship between IP strength and growth may be partly a placebo effect, where beliefs in the benefits of IP rather than actual use drive growth. This argument may apply to individual firms as well as to the economy as a whole.

From the perspective of a developing country, the most important patents are those taken out by the pharmaceutical sector and to lesser extent, the broader chemical sector. Because these patents are generally the most valuable, they are the most widely used by foreign multinationals, and their enforcement is likely to have the most negative impact on domestic social welfare. In Chile, for example, 60 per cent of patents are in pharmaceuticalchemical technologies, whereas in high income countries, the share of these technologies is 22 per cent. Similarly, 60 per cent of the non-resident filings in our sample of the countries acceding to the European Patent Convention after 2000 were in the pharmaceuticalchemical technologies before accession. The evidence on the impact of strengthening the patent system via TRIPS on the pharmaceutical sector in developing countries is nuanced: 1) it has had little effect on research directed to "neglected" diseases; 2) it does speed up the launch of new drugs.; and 3) some of the price impact is mitigated by other domestic policies. With respect to Chile, we found that there was use of secondary patenting by multinationals to extend patent term and little domestic impact on invention or patenting, at least in the short run. According to WIPO statistics, the majority of all Chilean patents (85 per cent) are still held by non-residents in 2017-2018, which is almost the same as in 19801981 (86 per cent), even though Chile itself has moved from a middle income to high income country during the same years and its real GDP per capita has more than tripled. 
Overall the investigations surveyed here support Penrose's view in 1951 and 1973 that patent system design might wish to take into account the development level of the economy in question. In addition, they highlight the relative unimportance of patents for domestic entities in these economies, even when a well-administered system exists, and suggest that patenting may not be a key tool in the development policy maker's toolkit.

\section{References}

Abraham, R. (2007). "Mobile Phones and Economic Development: Evidence From the Fishing Industry in India." Information Technologies and International Development 4(1): 48-56.

Abud Sittler, M. J., C. Fink, B. H. Hall, and C. Helmers (2013). The Use of Intellectual Property in Chile. Geneva, Switzerland: WIPO Economic Research Working paper 11. Available at http://www.wipo.int/publications/en/details.jsp?id=3955\&plang=EN

Abud Sittler, M. J., B. H. Hall, and C. Helmers (2015). “An Empirical Analysis of Primary and Secondary Pharmaceutical Patents in Chile". PLOS ONE. doi:10.1371/journal.pone.0124257

Aghion, P., M. Dewatripont and J. C. Stein (2008). "Academic freedom, private-sector focus, and the process of innovation." RAND Journal of Economics 39(3): 617-635.

Ahn. S., B. H. Hall, and K. Lee (eds.) (2014). Intellectual Property for Economic Development. KDI Series in Economic Policy and Development. Cheltenham, UK: Edward Elgar and KDI,

Allen, R.C. (2009). The British Industrial Revolution in Global Perspective. Cambridge, UK: Cambridge University Press.

Allred, B. and W. Park (2007). "Patent rights and innovative activity: evidence from national and firm-level data." Journal of International Business Studies 38 (6): 878-900.

Angeles, L. (2005). "Should Developing Countries Strengthen their Intellectual Property Rights?," BE Journal of Macroeconomics 5 (1), article 23.

Arora, A., X. Bei, and W. M. Cohen (2016): "Why Firms Trademark (or not): Evidence from the US Trademark Data." Academy of Management Annual Meeting Proceedings 2016(1): 17249. Available at https://journals.aom.org/doi/10.5465/ambpp.2016.17249abstract

Arora, A., L. Branstetter, and C. Chatterjee (2008). "Strong Medicine: Patent Reform and the Emergence of a Research-Driven Pharmaceutical Industry in India." NBER Conference paper.

Arora, A., M. Ceccagnoli, and W. M. Cohen (2008). "R\&D and the patent premium." International Journal of Industrial Organization 26: 1153-1179.

Balasubramanian, N. and J. Sivadasan (2011). "What happens when firms patent? New evidence from U.S. Economic census data." The Review of Economics and Statistics 93(1): 126-146.

Barton, J. H. (2004). "Issues posed by a world patent system." Journal of International Economic Law 7(2): 341-357. 
Baurzhan, S. and G. P. Jenkins (2016). "Off-grid solar PV: Is it an affordable or appropriate solution for rural electrification in Sub-Saharan African countries?" Renewable and Sustainable Energy Reviews 60: 1405-1418.

Braga C. A. O. and C. Fink (1998). "The Relationship Between Intellectual Property Rights and Foreign Direct Investment." Duke Journal of Comparative and International Law 9: 163-188.

Branstetter, L. G. (2004). "Do Stronger Patents Induce More Local Innovation?" Journal of International Economic Law 7(2): 359-370.

Branstetter, L.G., and Y. Nakamura (2003). “Is Japan's Innovative Capacity in Decline?,” in Blomström, M. (ed.), Structural Impediments to Growth in Japan. Chicago, IL: University of Chicago Press. Also National Bureau of Economic Research Working Paper Series No. 9438.

Branstetter, L.G., R. Fisman, and C.F. Foley (2006). "Do Stronger Intellectual Property Rights Increase International Technology Transfer? Empirical Evidence from U.S. FirmLevel Panel Data." Quarterly Journal of Economics 121 (1): 321-349.

Chen, Q. (2008). "The effect of patent laws on invention rates: Evidence from cross-country panels." Journal of Comparative Economics 36(4): 694-704.

Cimoli, M., G. Dosi, K. E. Maskus, R. L. Okediji, J. H. Reichman, and J. E. Stiglitz (eds.) (2014). Intellectual Property Rights: Legal and Economic Challenges for Development. Oxford: Oxford University Press.

Cockburn, I. M., J. O. Lanjouw, and M. Schankerman (2016). "Patents and the Global Diffusion of New Drugs." American Economic Review 106(1): 136-164. http://dx.doi.org/10.1257/aer.20141482

Cohen, W. M., R. R. Nelson, and J. P. Walsh (2000). Protecting Their Intellectual Assets: Appropriability Conditions and Why U.S. Manufacturing Firms Patent (or Not). Cambridge, MA: NBER Working Papers 7552.

Comino, S., A. Galasso and C. Graziano (2017). The Diffusion of New Institutions: Evidence from Renaissance Venice's Patent System. Cambridge: NBER Working Paper No. 24118.

David, P. A. (1994). "The Evolution of Intellectual Property Institutions." In Economics in a Changing World, Vol. 1: System Transformation: Eastern and Western Assessments, edited by A. Aganbegyan, O. Bogomolov, and M. Kaser. London: MacMillan..

Delgado, M., M. Kyle and A. M. McGahan (2013). "Intellectual Property Protection and the Geography of Trade." Journal of Industrial Economics 61(3): 733-762.

Deloitte Consulting (2012). What is the impact of mobile telephony on economic growth? A report for the GSM Association.

Dinwoodie, G. B. and R. C. Dreyfuss (2004). "International intellectual property law and the public domain of science." Journal of International Economic Law 7(2): 431-448.

Dosi, G., and J. E. Stiglitz (2014). “The Role of Intellectual Property Rights in the Development Process, with Some Lessons from Developed Countries: An Introduction." In M. Cimoli, G. Dosi, K. E. Maskus, R. L. Okediji, J. H. Reichman, and J. E. Stiglitz (eds.), Intellectual Property Rights: Legal and Economic Challenges for Development. Oxford: Oxford University Press. 
Duguet, E. and C. Lelarge (2012). "Does Patenting Increase the Private Incentives to Innovate? A Microeconometric Analysis." Annals of Economics and Statistics 107/108: 201-238.

Escobar Andrae, B. (2014). "The doctrines and the making of an early patent system in the developing world: The Chilean case. 1840s-1910s." Paper presented at the Workshop on International Diversity in Patent Cultures - A Historical Perspective, University of Leeds, UK.

European Commission, DG Competition (2009). Pharmaceutical Sector Inquiry: Final Report. Available at http://ec.europa.eu/competition/sectors/pharmaceuticals/inquiry/staff working paper part1.pdf

Farrell J, and C. Shapiro (2008). "How Strong Are Weak Patents?" American Economic Review 98(4): 1347-1369.

Feenstra, R. P., R. Inklaar, M. P. Timmer (2015). "The Next Generation of the Penn World Table." American Economic Review 105(10): 3150-3182. URL http://www.ggdc.net/pwt/

Fink, C., B. H. Hall, and C. Helmers (2020). "Intellectual Property use and firm performance: The case of Chile." Economic Development and Cultural Change, forthcoming 2020.

Fink, C., B. H. Hall, and C. Helmers (2018). "IP use in middle income countries: The case of Chile." Earlier version of preceding paper, available at https://eml.berkeley.edu// bhhall/papers/FinkHallHelmers18 NBERw24348.rev0 .pdf

Fink, C., C. Helmers, and C. J. Ponce (2018). "Trademark squatters: Theory and evidence from Chile," International Journal of Industrial Organization, forthcoming. Available at https://doi.org/10.1016/j.ijindorg.2018.04.004

Fink, C. and K. E. Maskus (2005). Intellectual Property and Development: Lessons from Recent Economic Research. Washington, D.C.: World Bank.

Foray, D., and L. Hilaire-Perez (2001). "The Economics of Open Technology: Collective Organization and Individual Claims in the 'Fabrique Lyonnaise' During the Old Regime." In C. Antonelli, D. Foray, B.H. Hall and W.E. Steinmueller (eds.), Essays in Honor of Paul A. David. Cheltenham, UK and Northampton, MA, USA: Edward Elgar.

Ginarte, J. C. and W. G. Park (1997). "Determinants of patent rights: A cross-national study." Research Policy 26(3): 283-301.

Gold, E. R., Morin, J.-F., and Shadeed, E. (2017). “Does intellectual property lead to economic growth? Insights from a novel IP dataset." Regulation \& Governance, doi: $10.1111 /$ rego.12165.

Grabowski, H. (2002). "Patents, Innovation and Access to New Pharmaceuticals." Journal of International Economic Law 5(4): 849-860.

Graham, S. J. H., B. H. Hall, D. Harhoff, and D. C. Mowery (2003). "Post-issue Patent 'Quality Control': A Comparative Study of U.S. Patent Re-examinations and European Patent Oppositions." In W. M. Cohen and S. A. Merrill (eds.), The Patent System in the Knowledge-Based Economy. Washington, DC: National Academies Press, 74-119. 
Grossman, G.M., and E.L.-C. Lai (2004). "International Protection of Intellectual Property," American Economic Review 94 (5): 1635-1653.

Hall, B. H. (2014). “Does patent protection help or hinder technology transfer?” In Ahn. S., B. H. Hall, and K. Lee (eds.), Intellectual Property for Economic Development. KDI Series in Economic Policy and Development. Cheltenham, UK: Edward Elgar and KDI, 1132.

Hall, B. H. (2011). "The Internationalization of R\&D." In Sydor, A. (ed.), Global Value Chains: Impacts and Implications, Trade Policy Research Report of Foreign Affairs and International Trade. Ottawa, Canada: Minister of Public Works and Government Services.

Hall, B. H. (2007). "Patents and Patent Policy." Oxford Review of Economic Policy 23(4): 1-20.

Hall, B. H. (2005). "Exploring the Patent Explosion." Journal of Technology Transfer 30: 3548.

Hall, B. H., S. J. H. Graham, D. Harhoff, and D. D. Mowery (2003). "Prospects for improving U.S. patent quality via post-grant opposition." Innovation Policy and the Economy 4: 115-143.

Hall, B. H., and D. Harhoff (2012). "Recent Research on the Economics of Patents." Annual Review of Economics 4: 541-566.

Hall, B. H., and C. Helmers (2019). "The impact of international patent systems: Evidence from accession to the European Patent Convention." Research Policy 48 (9): 103810. Available at https://doi.org/10.1016/j.respol.2019.103810

Hall, B. H., C. Helmers, and G. von Graevenitz (2015). "Technology Entry in the Presence of Patent Thickets." Cambridge, MA: NBER Working Paper No. 21455.

Hall, B. H., C. Helmers, M. Rogers and V. Sena (2013). "The importance (or not) of patents to UK firms." Oxford Economic Papers 65(3): 603-629.

Hall, B. H., A. Jaffe, and M. Trajtenberg (2005). "Market Value and Patent Citations." Rand Journal of Economics 36: 16-38.

Hall, B. H. and R. H. Ziedonis (2001). "The Determinants of Patenting in the U. S. Semiconductor Industry, 1980-1994." Rand Journal of Economics 32: 101-128.

Harhoff D., and M. Reitzig (2004). "Determinants of opposition against EPO patent grants: The case of biotechnology and pharmaceuticals." International Journal of Industrial Organization 22: 443-480.

Hasan, I. and C. Tucci (2010). "The innovation-economic growth nexus: Global evidence." Research Policy 39(10): 1264-1276.

Hu, A. G. Z. and I. P. L. Png (2013). "Patent rights and economic growth: evidence from crosscountry panels of manufacturing industries." Oxford Economic Papers 65(3): 675698.

ICTSD and UNCTAD. (2003). "Intellectual Property Rights, Implications for Development Policy." Geneva, Switzerland: ICTSD and UNCTAD Discussion Paper.

Ivus, 0. (2010). "Do stronger patent rights raise high-tech exports to the developing world?" Journal of International Economics 81(1): 38-47. 
James, T. C. (2007). "Patent Protection in India: Policy Trends." Presentation to the Conference on Intellectual Property Rights, Globalisation and Related Issues. Delhi, India: Delhi School of Economics.

JPO (Japanese Patent Office) (2006). A history of system of industrial property rights. Available at http://www.deux.jpo.go.jp/cgi/search.cgi?query=history\&lang=en\&root=short , accessed 19 December 2006.

Javorcik, B.S. (2002). "The Composition of Foreign Direct Investment and Protection of Intellectual Property Rights: Evidence from Transition Economies." European Economic Review 48: 39-62.

Kanwar, S. and R. Evenson (2003). "Does Intellectual Property Protection Spur Technical Change?" Oxford Economic Papers 55: 235-264.

Khan, B. Z. and K. L. Sokoloff (2001). "History Lessons: The Early Development of Intellectual Property Institutions in the United States." Journal of Economic Perspectives 15 (3): 233-246.

Kim, L. (2003), “Technology Transfer and Intellectual Property Rights: The Korean Experience." UNCTAD-ICTSD Issue Paper No. 2, June. Geneva: International Centre for Trade and Sustainable Development.

Kyle, M. K. and A. M. McGahan (2009). "Investments in Pharmaceuticals Before and After TRIPS." Review of Economics and Statistics 94(4): 1157-1172.

Kyle, M. K. and Y. Qian (2014). "Intellectual Property Rights and Access to Innovation: Evidence from TRIPS.” Cambridge, MA: NBER Working Paper No. 20799.

La Croix, S.J. and A. Kawaura (1996). "Product Patent Reform and Its Impact on Korea's Pharmaceutical Industry." International Economic Journal 10 (1): 109-124.

Lanjouw, J.O. (1997). "The Introduction of Pharmaceutical Product Patents in India: 'Heartless Exploitation of the Poor and Suffering'?" Cambridge, MA: NBER Working Paper No. 6366.

Lederman, D. and W.F. Maloney (2003). "R\&D and Development.” Washington, DC: The World Bank Policy Research Working Paper No. 3024. Available at SSRN: https://ssrn.com/abstract $=402480$

Lee, J.-Y., and E. Mansfield (1996). "Intellectual Property Protection and U.S. Foreign Direct Investment." Review of Economics and Statistics 78 (2): 181-186.

Lee, K. and Y.-K. Kim (2010). "IPR and Technological Catch-Up in Korea." In Odagiri, H. A. Goto, A. Sunami, R. R. Nelson (eds.), Intellectual Property Rights, Development, and Catch Up: An International Comparative Study. Oxford: Oxford University Press, 133167.

Lemley, M. A., and C. Shapiro (2007). "Patent holdup and royalty stacking.” Texas Law Review 85: 1991-2049.

Lerner, J. (2002). "Patent Protection and Innovation over 150 Years." American Economic Review 92 (2): 221-225.

Lerner, J. (1995). "Patenting in the shadow of competitors." Journal of Law and Economics 38: 463-95. 
Lin, J. X. and W. F. Lincoln (2017). "Pirate's treasure." Journal of International Economics 109: 235-245.

Machlup, F. and E. Penrose (1950). "The Patent Controversy in the Nineteenth Century." Journal of Economic History 10 (1): 1-29.

MacLeod, C. and A. Nuvolari (2016). "Inventive Activities, Patents and Early Industrialisation: A Synthesis of Research Issues." Rivista di storia economica XXXII (1): 77-108.

Mansfield, E. (1994). “Intellectual Property Protection, Foreign Direct Investment, and Technology Transfer." Washington, DC: International Finance Corporation Discussion Paper No. 19.

Mansfield, E. (2000). “Intellectual Property Protection, Direct Investment and Technology Transfer: Germany, Japan and the USA." International Journal of Technology Management 19 (1/2): 3-21.

Maskus, K. E. (2004). “Encouraging International Technology Transfer.” Geneva, Switzerland: ICTSD and UNCTAD Issue Paper No. 7.

Maskus, K. E. and M. Penubarti (1995). "How trade-related are intellectual property rights?" Journal of International Economics 39(3): 227-248.

Mokyr, J. (2009). “Intellectual Property Rights, the Industrial Revolution, and the Beginnings of Modern Economic Growth. American Economic Review 99 (2): 349-355.

Moser, P. (2013). "Patents and Innovation: Evidence from Economic History.” Journal of Economic Perspectives 27 (1): 23-44.

Moser, P. (2005). "How Do Patent Laws Influence Innovation? Evidence from NineteenthCentury World's Fairs.” American Economic Review 95 (4): 1214-1236.

Mossoff, A. (2001). "Rethinking the Development of Patents: An Intellectual History, 15501800." Hastings Law Journal 52: 1255-1322.

Murmann, J.P. (2003). Knowledge and Competitive Advantage: The Coevolution of Firms, Technology, and National Institutions. New York: Cambridge University Press.

Neubig, T. S., and S. Wunsch-Vincent (2017). "A missing link in the analysis of global value chains: cross-border flows of intangible assets, taxation and related measurement implications." Geneva: WIPO Economic Research Paper No. 37.

Nuvolari, A. (2004). "Collective invention during the British Industrial Revolution: the case of the Cornish pumping engine." Cambridge Journal of Economics 28(3): 347-363.

OECD (2009). Innovation in Firms: A Microeconomic Perspective. Paris: OECD Publications.

Ondraczek, J. (2014). "Are we there yet? Improving solar PV economics and power planning in developing countries: The case of Kenya." Renewable and Sustainable Energy Reviews 30: 604-615.

Park, W. G. (2017). "Averting a "TRIPSxit from the global intellectual property system." George Mason Law Review 24(4): 883-906.

Park, W. G. (2008). "International patent protection: 1960-2005." Research Policy 37(4): 761-766. 
Park, W.G. and D.C. Lippoldt (2008). "Technology Transfer and the Economic Implications of the Strengthening of Intellectual Property Rights in Developing Countries." OECD Trade Policy Working Papers No. 62. doi:10.1787/244764462745

Penrose, E. T. (1973). “International patenting and the less-developed countries.” Economic Journal 83 (Sept.): 768-786.

Penrose, E. T. (1969). "Problems associated with the growth of international firms." The Rhodesian Journal of Economics 3 (4): 1-7.

Penrose, E. T. (1951). The Economics of the International Patent System. Johns Hopkins University Studies in Historical and Political Science. Baltimore: The Johns Hopkins Press.

Prager, F. D. (1946). “Brunelleschi's Patent.” Journal of the Patent Office Society 28(2): 109135.

de Rassenfosse, G., P. H. Jensen, T. Julius, A. Palangkaraya, and E. Webster (2020). “Are Foreigners Treated Equally under the Trade-Related Aspects of Intellectual Property Rights Agreement?" Journal of Law and Economics 62(4): 663-685.

Qian, Y. (2007). "Do Additional National Patent Laws Stimulate Domestic Innovation in a Global Patenting Environment." Review of Economics and Statistics 89(3): 436-453.

Sakakibara, M., and L.G. Branstetter (2001). "Do Stronger Patents Induce More Innovation? Evidence from the 1988 Japanese Patent Law Reforms," Rand Journal of Economics 32 (1): 77-100.

Sampat, B. N. and K. C. Shadlen (2017). "Secondary pharmaceutical patenting: A global perspective." Research Policy 46: 693-707.

Scherer, F. M. and S. Weisburst (1995). "Economic Effects of Strengthening Patent Protection in Italy." International Review of Industrial Property and Copyright Law 26(6): 1009-1024.

Scotchmer, S. (2004). "The Political Economy of Intellectual Property Treaties.” Journal of Law, Economics, and Organization 20 (2): 415-437.

Shapiro, C. (2010). "Injunctions, Hold-Up, and Patent Royalties." American Law and Economics Review 12(2): 280-318.

Siegel, M. and S. Fransen (2013). "New Technologies in Remittance Sending: Opportunities for mobile remittances in Africa." African Journal of Science, Technology, Innovation and Development 5(5): 423-438.

Smith, P.J. (1999), “Are Weak Patent Rights a Barrier to U.S. Exports?” Journal of International Economics, 48 (1), 151-177.

Smith, P.J. (2001), “How Do Foreign Patent Rights Affect U.S. Exports, Affiliate Sales, and Licenses?” Journal of International Economics, 55 (2), 411-439.

Thursby, J.G., and M. Thursby (2006). Here or There? A Survey of Factors in Multinational $R \& D$ Location. Washington, DC: National Academies Press.

Turner, J.L., and P. Heald (2004). Intellectual Property and Foreign Direct Investment: Improving upon Mansfield's 1991 Survey, Preliminary Report. Atlanta, GA: University of Georgia. Available at http://media.terry.uga.edu/myila/pdf/RRTurner.pdf 
Vaitsos, C. (1972). "Patents revisited: Their function in developing countries." The Journal of Development Studies 9(1): 71-97.

Weisburst, S. and F. M. Scherer (1995). "Economic Effects of Strengthening Patent Protection in Italy." International Review of Industrial Property and Copyright Law 26 (6): 1009-1024.

WIPO (World Intellectual Property Organization) (2018). PCT Yearly Review 2018 Executive Summary. Available at https://www.wipo.int/ipstats , accessed 30 August 2018.

WIPO (World Intellectual Property Organization) (2017). Patent statistics, available at https://www3.wipo.int/ipstats/index.htm?tab=patent , accessed 1 March 2018.

WIPO (World Intellectual Property Organization) (2016). World Intellectual Property Indicators 2016. Available at http://www.wipo.int/edocs/pubdocs/en/wipo pub 941 2016.pdf

Yang, L. and K.E. Maskus (2009). "Intellectual Property Rights, Technology Transfer and Exports in Developing Countries." Journal of Development Economics 90: 231-236.

Zuniga, M. P. and E. Combe (2002). "Introducing Patent Protection in the Pharmaceutical Sector: a First Evaluation for the Mexican Case." Revue Région et Développement 16: 191-221. 